\title{
Pengembangan Alur Pasien dan Berkas Rekam Medis sebagai Optimalisasi Sistem Informasi Rekam Medis
}

\section{Development of Patient Stages and Medical Record Document as Medical Record Information System Optimization}

\author{
Agni Hadi $P^{1}$, Tita Hariyanti ${ }^{1}$, Sugeng Susilo ${ }^{2}$ \\ ${ }^{1}$ Program Studi Magister Manajemen Rumah Sakit Fakultas Kedokteran Universitas Brawijaya Malang
}

${ }^{2}$ Rumah Sakit Paru Batu Malang

\begin{abstract}
ABSTRAK
Alur sistem dan dokumen merupakan komponen penting dalam sistem informasi rekam medis baik berbasis komputer maupun konvensional. Tujuan dari penelitian ini adalah mengidentifikasi alur pasien dan berkas rekam medis yang sesungguhnya untuk merancang rekomendasi alur pasien dan alur berkas rekam medis. Data diperoleh dari wawancara dengan perawat Instalasi Gawat Darurat (IGD), rawat inap, koordinator keperawatan, penanggung jawab bidang layanan medis dan keperawatan, serta petugas rekam medis sebagai dasar dalam pengembangan alur pasien dan alur berkas rekam medis. Data menunjukkan alur yang diterapkan di rumah sakit terlalu panjang dan pada pasien rawat inap yang datang kembali tidak mendapatkan berkas rekam medis. Alur pasien IGD dan berkas rekam medis rawat inap belum sesuai dengan alur yang ditetapkan oleh Depkes RI. Alur pasien rawat jalan, rawat inap dan alur berkas rekam medis pasien rawat jalan sudah sesuai dengan alur yang ditetapkan oleh Depkes RI walaupun pada pengelolaan berkas rekam medis masih terdapat kekurangan. Untuk meningkatkan efisiensi alur perlu adanya tenaga distribusi, pemotongan alur Instalasi Gawat Darurat, dan pasien lama mendapatkan berkas rekam medis sebelumnya, serta koordinasi antara petugas rekam medis dan petugas pendaftaran rawat inap saat ada pasien lama kembali ke rumah sakit.
\end{abstract}

Kata Kunci: Alur pasien, alur rekam medis, dokumen

\begin{abstract}
System and document workflow are important components in medical record information system both computer-based and conventional. The purpose of this study is to identify the actual stages of patients and medical record file for drafting recommendation on stages of patients and medical record file. The data were obtained from interviews with ER nurses, inpatient nurses, nurse coordinators, area coordinators of medical and nursing services, and medical record personnel as the basis for the development of stages of patient and medical record file. The data show that the stages applied are too long and hospitalized patients coming back do not get the medical record file. Stages for ER and inpatient patients and medical record file are in accordance with the mechanism established by the Ministry of Health although the medical record file management is still incomplete. To improve the stages efficiency, it is necessary to have distribution officer, cut the stages for $E R$, and provide the patients to get medical record file, as well as coordination between medical record officer and admission officer when the patients are coming back to the hospital.
\end{abstract}

Keywords: Document flow, medical record, patient flow

Jurnal Kedokteran Brawijaya, Vol. 28, Suplemen No. 2, 2015; Korespondensi: Agni Hadi P. Program Studi Magister Manajemen Rumah Sakit Fakultas Kedokteran Universitas Brawijaya Malang, Jl. Veteran Malang 65145 Tel. (0341) 569117 Email: agni_pratiwi@yahoo.com 


\section{PENDAHULUAN}

Sistem Informasi Manajemen Rumah Sakit (SIMRS) memainkan peran yang sangat besar dan berpengaruh di dalam rumah sakit. Penggunaan SIMRS dapat meningkatkan efisiensi dalam memberikan pelayanan kesehatan. Selain itu, penggunaan SIMRS juga dapat meningkatkan efektifitas, akurasi, dan mencegah kesalahan dalam proses memasukkan data (1). Menurut beberapa penelitian yang disebutkan dalam sistem informasi di rumah sakit juga berperan dalam meningkatkan sharing informasi kesehatan. Informasi kesehatan tersebut dapat berfungsi untuk meningkatkan keselamatan pasien, kecepatan pelayanan, mengurangi sampah, membantu pelayanan pasien center, dan mendukung kesehatan masyarakat. Selain itu menurut Vest et al adanya sistem informasi di rumah sakit juga akan meningkatkan keuntungan rumah sakit, meningkatkan kualitas pelayanan dan menghemat biaya rumah sakit (2). Sementara menurut review Fichman et al dari hasil riset Kane dan Labianca ada hubungan penggunaan sistem informasi dengan efisiensi pelayanan, kepuasan pasien, dan kualitas dari pelayanan di rumah sakit (3).

Rumah Sakit Paru Batu merupakan rumah sakit khusus paru milik Propinsi Jawa Timur sebagai rumah sakit tipe B khusus paru. Dari hasil studi pendahuluan di RS Paru Batu ditemukan adanya sistem informasi manejemen rumah sakit yang belum terintegrasi antar unit. Sistem yang belum terintegrasi ini tidak hanya pada SIM yang berbasis komputer tetapi juga SIM berbasis konvensional. Berdasarkan hasil wawancara dengan beberapa perawat instalasi gawat darurat (IGD) dan rawat inap SIM yang berbasis komputer belum terintegrasi dikarenakan tidak adanya tenaga pemeliharaan program SIM.

Salah satu bentuk SIM adalah sistem informasi rekam medis. Sistem informasi rekam medis digunakan mulai dari pendaftaran pasien, pemeriksaan, perencanaan perawatan, perawatan yang diberikan kepada pasien hingga pasien pulang dari rumah sakit $(1,4-6)$. Sistem informasi rekam medis merupakan salah satu sistem informasi yang penting. Hal tersebut dikarenakan rekam medis tidak hanya digunakan untuk pengobatan saja akan tetapi rekam medis juga digunakan untuk coding, pembayaran, jaminan kesehatan, audit, bukti dalam proses hukum, penelitian epidemiologi, penilaian kinerja tenaga kesehatan dan rumah sakit (7). Selain itu menurut Rosenthal et al rekam medis juga dapat berfungsi untuk mencegah terjadinya error. Sistem informasi rekam medis baik berbasis komputer maupun konvensional harus terselenggara dengan baik sebagai wujud dari perawatan dan pelayanan pasien yang baik (8). Menurut Budi pelayanan akan berjalan dengan efektif jika petugas bekerja sesuai dengan alur yang telah ditentukan (9).

Dalam sistem informasi rekam medis terdapat 2 alur, yaitu alur pasien dan alur berkas rekam medis. Alur pasien menggambarkan tentang bagan pelayanan pasien mulai dari pasien masuk hingga pasien keluar. Alur berkas rekam medis memberikan gambaran tentang bagan berkas rekam medis dimulai dari dikeluarkannya berkas saat pasien masuk hingga berkas tersebut disimpan dalam tempat penyimpanan. Alur pasien dan alur rekam medis dapat membantu petugas dalam melayani pasien. Alur tersebut dapat menjadikan pelayanan cepat dan tepat. Selain itu, alur pasien dan alur rekam medis dapat dijadikan sebagai dasar pembuatan sistem informasi berbasis komputer. Menurut Susanto dan Sukadi alur dapat digunakan untuk penggambaran analisis maupun rancangan baik secara manual maupun terkomputerisasi (10). Hal ini didukung oleh Kusumarini yang menyatakan dari alur peresepan yang praktis akan tercipta SIM yang efektif (11). Akan tetapi, hasil wawancara dengan perawat Instalasi Gawat Darurat (IGD) RS Paru Batu, menyatakan bahwa alur pasien belum dijalankan dengan baik karena dari segi manusia, petugas IGD tidak ingin bertanggung jawab atas stok obat yang ada di IGD dan tidak ada tenaga administrasi di IGD.

Pada segi metode, SOP (Standar Operasional Prosedur) yang ada belum mengatur alur pasien IGD dengan baik dan belum ada kebijakan penanggung jawab perekapan obat, serta belum ada alur pasien yang dapat dilihat oleh pasien. Pada segi material, pasien pulang tanpa membayar pelayanan yang telah diberikan kepada pasien di IGD dan pasien pulang dengan membawa obat dan alat kesehatan. Sementara hasil wawancara dengan petugas rekam medis, alur berkas rekam medis pasien rawat inap juga belum berjalan dengan baik. Ditinjau dari manusia menunjukkan tidak ada tenaga distribusi berkas rekam medis dan perawat tidak menghubungi bagian rekam medis jika ada pasien lama kembali masuk serta kurangnya motivasi perawat dan dokter untuk melengkapi dan mengembalikan berkas rekam medis tepat waktu. Segi metode, belum ada SOP yang jelas tentang alur berkas rekam medis rawat inap serta belum ada dukungan yang optimal dari pihak manajemen rumah sakit untuk mengoptimalisasikan alur rekam medis. Pada segi material, kurangnya pengetahuan pasien akan pentingnya keberlanjutan informasi serta berkas rekam medis terbawa pulang oleh pasien (terutama pada pasien rawat jalan). Dari permasalahan tersebut maka tujuan dari penelitian ini adalah mengkaji alur pasien yang berjalan pada saat ini, merekomendasikan alur pasien, mengkaji alur berkas rekam medis serta merekomendasikan alur berkas rekam medis.

\section{METODE}

Untuk mengidentifikasi alur pasien di IGD dilakukan wawancara dengan perawat IGD serta melihat SOP alur pasien IGD. Identifikasi alur pasien rawat jalan dilakukan dengan melakukan time and motion study yang dilakukan pada tanggal 29 dan 30 September 2014 pada dua pasien rawat jalan. Pengamatan dilakukan mulai dari pasien datang hingga pasien pulang sedangkan identifikasi alur pasien rawat inap dilakukan melalui wawancara dengan perawat rawat inap dan pengamatan alur berkas rekam medis pasien rawat inap yang dilakukan pada tanggal 30 September 2014.

Identifikasi alur berkas rawat inap dilakukan melalui wawancara dengan petugas rekam medis. Selain itu, juga dilakukan pengamatan langsung dengan terlibat dalam aktivitas kegiatan pengelolahan berkas rekam medis di unit rekam medis RS pada tanggal 11 Oktober 2014. Untuk mengidentifikasi alur berkas rawat jalan hanya dilakukan wawancara dengan petugas rekam medis. Hal tersebut dilakukan karena pengelolahan berkas rekam medis rawat jalan dan rawat inap dilakukan secara terpisah. Informasi lain seperti penyebab kurang berjalannya alur pasien dan alur berkas rekam medis secara optimal dilakukan melalui proses diskusi dengan penanggung jawab bidang pelayanan medis dan keperawatan, koordinator keperawatan, dan perawat rawat inap. 
HASIL

Hasil penelitian merupakan hasil temuan selama observasi dan beberapa rekomendasi yang dibuat dari hasil temuan tersebut. Rekomendasi tersebut terdiri atas alur pasien dan alur berkas rekam medis. Alur pasien yang dibuat meliputi alur pasien rawat jalan, rawat inap dan gawat darurat. Berikut ini merupakan alur pasien rawat jalan, rawat inap dan gawat darurat dari hasil temuan selama proses magang.

Alur pasien rawat jalan di RS Paru Batu dimulai dari pasien masuk kemudian pasien mendaftar dan masuk ke poliklinik yang dituju. Di poliklinik akan ditentukan apakah pasien tersebut membutuhkan pelayanan penunjang atau tidak. Jika pasien tidak membutuhkan pelayanan penunjang pasien dapat langsung ke bagian administrasi dan ke bagian farmasi untuk membeli obat yang telah diresepkan oleh dokter. Pada pasien yang membutuhkan pelayanan penunjang pasien harus kembali ke administrasi kemudian ke unit penunjang yang telah disarankan oleh dokter. Setelah mendapatkan pelayanan dari unit penunjang maka pasien akan kembali ke poliklinik. Di poliklinik dokter akan membaca hasil dari pemeriksaan yang dilakukan di pelayanan penunjang. Dari hasil tersebut maka dokter akan mediagnosa penyakit yang diderita pasien dan memberikan informasi kepada pasien dan keluarganya tentang perencanaan pelayanan kesehatan yaitu: pemberian obat dan pulang atau memerlukan rawat inap. Jika pasien dirasa hanya membutuhkan terapi obat dan diperbolehkan pulang maka pasien langsung ke bagian administrasi dilanjutkan ke bagian farmasi dan pulang. Jika pasien harus rawat inap maka pasien atau keluarga pasien harus mendaftar kebagian Tempat Pendaftaran Pasien (TPP) rawat inap. Setelah keluarga atau pasien mendaftar pasien dapat langsung dibawa ke bangsal perawatan.

Hasil wawancara pada perawat rawat inap dan observasi dari berkas rekam medis pasien, alur pasien rawat inap dimulai dari IGD atau poliklinik. Pasien yang sudah mendaftar dibagian TPP rawat inap akan dibawa ke bangsal perawatan. Di bangsal perawatan pasien akan mendapatkan perawatan sesuai dengan kebutuhan pasien. Jika pasien membutuhkan pelayanan penunjang maka pasien akan dibawa ke unit penunjang yang dibutuhkan. Setelah mendapatkan pemeriksaan dari pelayanan penunjang, dokter akan membaca hasil pemeriksaan. Hasil pemeriksaan tersebut yang akan digunakan untuk menentukan perawatan yang akan diberikan kepada pasien. Saat pasien sudah diijinkan untuk pulang maka pasien atau keluarga pasien harus menyelesaikan administrasi dan menuju bagian farmasi untuk membeli obat yang sudah diresepkan oleh dokter. Hasil temuan lain pada alur pasien rawat inap adalah perawat ruangan mengharuskan pasien poliklinik yang akan menjalani rawat inap harus kembali ke IGD untuk mendapatkan surat pengantar rawat inap dari IGD. Alur tersebut menyulitkan pasien dan keluarga pasien karena keluarga pasien harus kembali ke IGD setelah sampai di ruang rawat inap.

Pada alur pasien gawat darurat tanpa rawat inap di RS Paru Batu berdasarkan hasil wawancara dengan perawat IGD hampir sama dengan alur pasien rawat jalan. Perbedaan alur tersebut terletak pada alur IGD lebih panjang dibandingkan dengan alur pasien rawat jalan. Hal tersebut disebabkan karena petugas merasa takut bertanggung jawab atas kehilangan obat. Alur IGD di RS Paru dimulai dari identifikasi berdasarkan kegawatannya. Pasien yang diantar oleh keluarga, maka keluarga harus mendaftarkan pasien di loket pendaftaran terlebih dahulu sementara

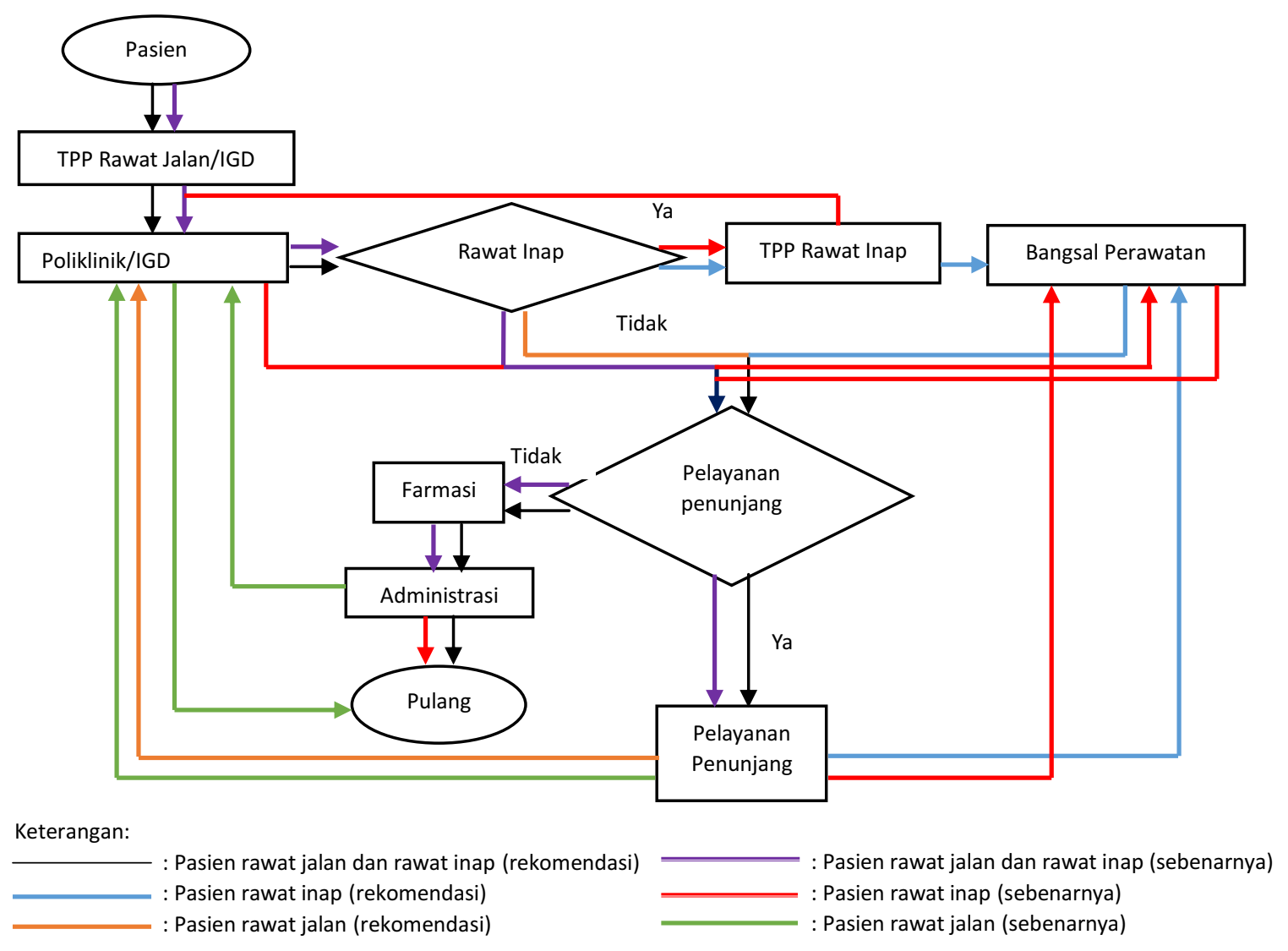

Gambar 1. Alur pasien rekomendasi dan sebenarnya 
pasien segera mendapatkan tindakan dari petugas IGD. Jika dokter IGD merasa pasien membutuhkan pelayanan penunjang maka pasien akan dibawa ke unit penunjang yang dibutuhkan. Setelah pasien mendapatkan pelayanan di unit penunjang maka pasien akan dibawa kembali ke IGD beserta hasilnya. Di IGD dokter akan membaca hasil pemeriksaannya dan menentukan rencana pelayanan kesehatan yang akan diberikan. Jika pasien dirasa tidak membutuhkan rawat inap maka keluarga pasien dapat melakukan pembayaran dibagian administrasi dan ke bagian farmasi. Di bagian farmasi pasien tidak hanya membeli resep obat yang akan diminum di rumah akan tetapi juga membeli obat atau alat kesehatan yang telah dipakai oleh pasien saat mendapat tindakan di IGD. Selanjutnya pasien atau keluarga pasien harus kembali ke IGD untuk mengganti obat dan alat kesehatan yang telah dipakai dan menunjukkan bukti administrasi. Setelah mengganti dan menunjukkan bukti administrasi, pasien diperbolehkan pulang.

Berdasarkan hasil wawancara dengan perawat IGD, pada alur pasien gawat darurat yang menjalani rawat inap, keluarga pasien/pasien harus ke bagian farmasi dan administrasi dahulu kemudian keluarga pasien/pasien kembali ke IGD untuk menunjukkan bukti pembayaran. Keluarga pasien/pasien yang telah menunjukkan bukti pembayaran dan pasien dinyatakan harus rawat inap maka keluarga pasien/pasien harus menuju TPP rawat inap kemudian kembali ke IGD dengan membawa berkas rekam medis. Berkas rekam medis tersebut diisi oleh petugas IGD dan diberi surat pengantar rawat inap. Setelah semua berkas dilengkapi pasien diantar menuju bangsal perawatan. Alur pasien rekomendasi dan hasil pengamatan (sebenarnya) disajikan pada Gambar 1.

Hasil wawancara dengan petugas rekam medis, alur berkas rekam medis pasien rawat jalan di RS Paru Batu dibedakan berdasarkan rekam medis pasien lama dan pasien baru. Untuk pasien baru akan mendapatkan berkas rekam medis di Tempat Pendaftaran Pasien (TPP). Untuk pasien lama akan diambilkan berkas rekam medisnya di bagian filling (penyimpanan). Gambar 2 menyajikan alur berkas rekam medis pasien rawat jalan di RS Paru Batu.

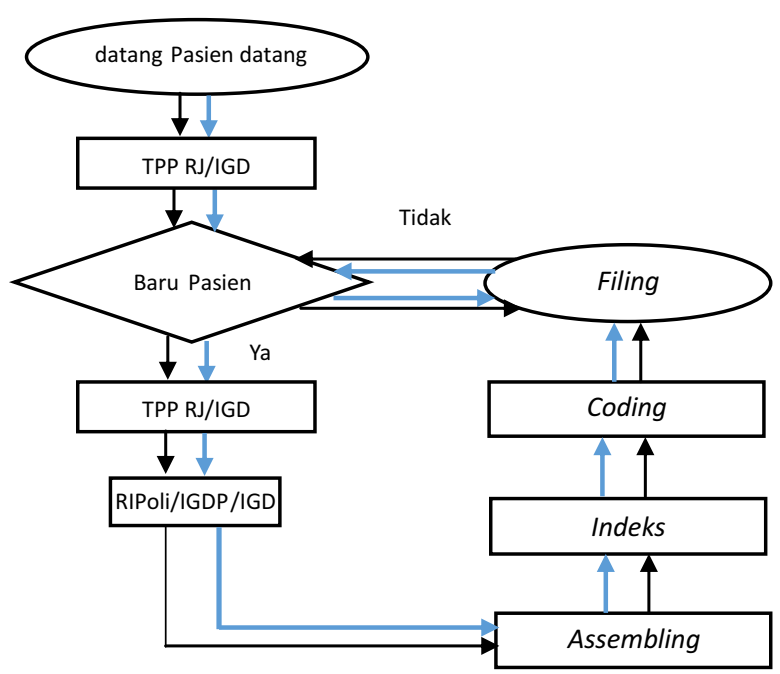

Keterangan:

: Alur berkas rekam medis sebenarnya

: Alur berkas rekam medis rekomendasi
Alur yang cukup panjang ditemukan pada pasien dari IGD yang perlu menjalani rawat inap. Ketika pasien sadar dan dapat diwawancarai yang melakukan wawancara adalah petugas IGD. Petugas IGD kemudian mendatangi keluarga pasien dan diminta untuk membeli obat yang telah diresepkan ke bagian farmasi dan menyelesaikan administrasi. Setelah itu keluarga pasien harus mendaftarkan pasien ke TPP rawat inap. Di TPP pasien diberikan berkas rekam medis baru walaupun pasien tersebut merupakan pasien lama. Setelah mendapatkan berkas rekam medis, keluarga pasien harus membawa berkas rekam medis tersebut ke IGD kemudian petugas IGD melengkapi berkas rekam medis tersebut dan memberi surat keterangan rawat inap. Setelah berkas tersebut dilengkapi maka berkas tersebut dibawa ke ruang rawat inap bersama dengan pasien yang akan menjalani rawat inap.

Hasil wawancara dengan petugas rekam medis tentang alur berkas rekam medis pasien rawat inap di RS Paru Batu, berkas rekam medis untuk pasien rawat inap tidak dibedakan berdasarkan pasien lama dan pasien baru. Semua pasien baik pasien lama maupun pasien baru akan mendapatkan berkas rekam medis baru dengan nomor rekam medis yang sama. Berkas rekam medis tersebut akan disertakan dengan pasien ketika pasien masuk ke bangsal perawatan. Berkas rekam medis akan diberikan ke unit rekam medis pada saat pasien pulang. Di beberapa ruang rawat inap, rekam medis tidak langsung dikembalikan ke unit rekam medis, terkadang berkas rekam medis baru dikembalikan ke unit rekam medis setelah beberapa minggu atau beberapa bulan setelah pasien pulang.Berkas rekam medis yang masuk ke unit rekam medis langsung dilakukan proses perakitan, pengkodean dan pengindeksan setelah itu berkas rekam medis yang baru akan digabung dengan berkas rekam medis yang lama atau langsung disimpan pada rak penyimpanan. Gambar 3 menyajikan alur berkas rekam medis rawat inap baik yang terjadi serta rekomendasi yang diusulkan.

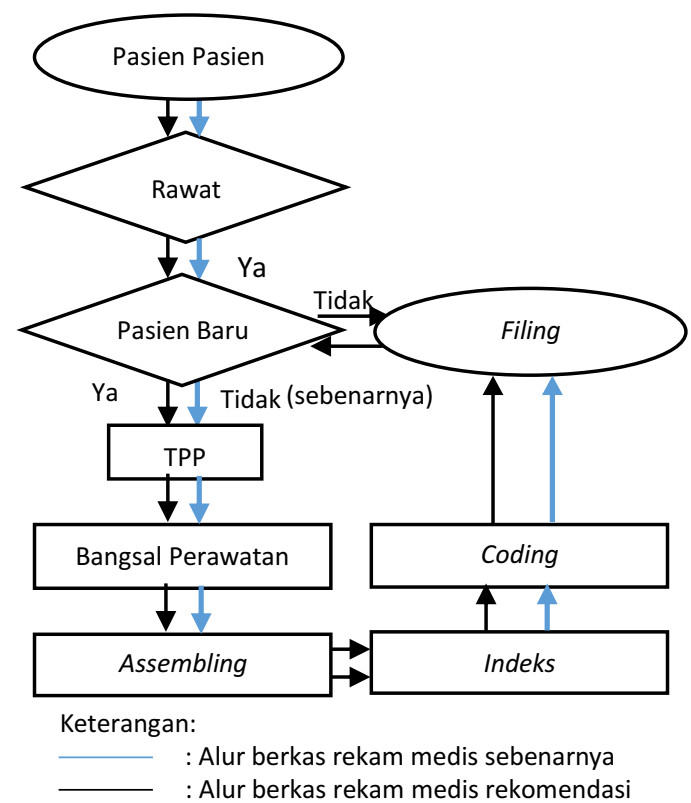
dan sebenarnya
Gambar 3. Alur berkas rekam medis rawat inap rekomendasi
Gambar 2. Alur berkas rekam medis rawat jalan rekomendasi dan sebenarnya 


\section{DISKUSI}

\section{Penerimaan Pasien Rawat Jalan}

Menurut Departemen Kesehatan RI, penerimaan pasien rawat jalan dibedakan menjadi alur pasien baru dan lama (12). Pasien baru diterima di TPP dan diwawancarai oleh petugas. Pasien baru akan memperoleh nomor pasien. Setelah proses pendaftaran selesai, pasien baru dipersilahkan menunggu di poliklinik yang dituju dan petugas rekam medis mempersiapkan berkas rekam medisnya lalu dikirim ke poliklinik tujuan pasien. Pasien lama yang datang ke rumah sakit akan mendapatkan pelayanan di TPP. Pasien yang datang dengan perjanjian dapat langsung menuju poliklinik. Pasien yang datang tanpa perjanjian harus menunggu petugas mengambil berkas rekam medis dibagian penyimpanan. Setelah berkas rekam medis ditemukan maka berkas rekam medis tersebut dikirim ke poliklinik oleh petugas, selanjutnya pasien akan mendapat pelayanan kesehatan di poliklinik yang dituju. Setelah pasien poliklinik selesai berobat maka semua berkas rekam medis kembali ke unit rekam medis, kecuali pasien yang harus dirawat, rekam medisnya akan dikirim ke ruang perawatan.

Berdasarkan hasil time and motion study pada pasien rawat jalan di RS Paru Batu proses penerimaan pasien baru sudah sesuai dengan yang ditentukan oleh Depkes RI. Perbedaannya antara ketentuan Depkes RI dan hasil observasi terletak pada pembawa rekam medis dari ruang rekam medis menuju poliklinik. Menurut ketentuan Depkes RI, rekam medis yang telah disiapkan, akan dibawa oleh petugas rekam medis ke poliklinik. Di RS Paru Batu berkas rekam medis diberikan kepada pasien atau keluarga pasien kemudian pasien atau keluarga pasien akan membawa berkas rekam medis tersebut ke poliklinik yang dituju. Berkas rekam medis merupakan catatan medis, dimana kerahasiaan isi di dalam rekam medis harus dijaga. Rekam medis yang ada dibawa sendiri oleh pasien atau keluarga pasien mempunyai risiko rekam medis akan terbawa pulang saat pasien membatalkan pelayanan kesehatannya. Selain itu, jika yang membawa bukan pasien sendiri, maka kerahasiaan rekam medis sudah tidak terlindungi. Rahasia medis adalah rahasia milik pasien. Rahasia itu didokumentasikan di dalam rekam medis pasien yang harus disimpan dengan baik. Isi rekam medis tidak boleh diketahui atau dibaca oleh sembarang orang tanpa persetujuan pasiennya. Berkas rekam medis adalah milik rumah sakit yang tidak boleh dibawa keluar rumah sakit oleh siapapun, termasuk dokter dan pasiennya sendiri (13).

\section{Penerimaan Pasien Gawat Darurat}

Prosedur bagi pasien datang ke tempat penerimaan pasien gawat darurat berbeda dengan prosedur pelayanan pasien baru dan pasien lama pada poliklinik, di IGD pasien ditolong terlebih dahulu. Setelah mendapatkan pertolongan pasien atau keluarga pasien dapat menyelesaikan proses administrasi. Setelah mendapatkan pelayanan ada beberapa kemungkinan dari setiap pasien, yaitu: pasien boleh langsung pulang, pasien dirujuk ke rumah sakit lain, pasien harus dirawat.

Pada pasien gawat darurat di RS Paru Batu berdasarkan hasil wawancara dengan perawat IGD pasien dengan keadaan gawat akan ditolong terlebih dahulu kemudian menyelesaikan proses administrasi. Akan tetapi penyelesaian administrasi setelah dilakukan pelayanan dapat mengakibatkan pasien langsung pulang tanpa membayar. Oleh karena itu, IGD memerlukan bagian administrasi tersendiri. Pengisian tenaga administrasi dapat dilakukan proses analisa beban kerja untuk mengetahui administrasi tersebut perlu dikerjakan oleh orang lain atau menggunakan tenaga IGD yang ada. Selain penambahan bagian administrasi juga perlu ditunjang dengan pengembangan SIM RS berbasis komputer.

Hasial mengidentifikasi laur yang panjang pada pelayanan pasien rawat inap dari IGD. Alur yang direkomendasikan oleh Depkes RI secara singkat pasien dari IGD dapat langsung ke bangsal perawatan tanpa harus ke administrasi dan farmasi. Hal yang sama juga diungkapkan oleh Budi bahwa alur pasien IGD yang menjalani rawat inap dapat melalui proses pasien dari IGD ke TPP RI dan ke bangsal perawatan (9). Alur yang panjang dapat mengurangi kepuasan pasien. Ketidakpuasan pasien berarti menandakan bahwa RS Paru Batu belum sepenuhnya berhasil untuk mencapai visinya yang berisi "menjadi rumah sakit utama pilihan masyarakat". Hal ini didukung oleh penelitian dari Nursa'adah yang menyatakan bahwa alur yang sederhana akan berdampak pada efisien dan efektivitas dalam perkembangan pelayanan (14). Selain itu, alur yang sederhana akan memudahkan pelanggan dalam mendapatkan pelayanan. Oleh karena itu, alur simplifikasi alur pelayanan akan menciptakan tingkat kepuasan yang tinggi. Penelitian lain yang mendukung adalah penelitian Mukti et al menyatakan bahwa kecepatan dan ketepatan alur pelayanan akan meningkatkan kepuasan pasien (15).

\section{Penerimaan Pasien Rawat Inap}

Penerimaan pasien rawat inap dimulai dengan mendaftar di Tempat Pendaftaran Pasien Rawat Inap (TPP RI). Pada saat mendaftar pasien akan mendapatkan penjelasan tentang tanggal masuk, biaya perawatan, serta aturan selama perawatan. Setelah itu petugas membuat kartu identitas pasien. Jika pasien merupakan pasien lama, maka petugas TPP RI dapat menghubungi unit rekam medis untuk meminta berkas rekam medis pasien (12).

Hasil observasi pada berkas rekam medis pasien dan hasil wawancara dengan perawat IGD didapatkan perbedaan antara alur penerimaan pasien di RS Paru Batu dengan standar alur yang ditetapkan oleh Depkes RI. Di RS Paru Batu pasien yang datang dari IGD harus ke TPP RI untuk mendaftar, kemudian pasien harus kembali ke IGD untuk mendapatkan surat pengantar rawat inap dan pengisian dokumen rekam medis. Selain itu, ada beberapa perawat ruangan mengharuskan pasien poliklinik yang akan menjalani rawat inap harus kembali ke IGD untuk mendapatkan surat pengantar rawat inap dari IGD. Hal tersebut mencerminkan alur yang kurang efektif. Menurut Suharyanta (16) alur yang kurang efektif berpengaruh tidak langsung terhadap kualitas pelayanan. Selain itu, pada pasien lama yang datang kembali akan mendapatkan berkas rekam medis yang baru dengan nomer rekam medis yang lama. Menurut Kumar et al pemanggilan berkas rekam medis yang lama atau retrival merupakan hal yang penting. Hal tersebut dikarenakan dokter dapat memberikan pelayanan yang efektif dengan melihat catatan pada kunjungan sebelumnya (17).

\section{Alur Berkas Rekam Medis Rawat Jalan dan Rawat Inap}

Pasien yang datang ke TPP RJ dibedakan atas pasien lama dan pasien baru. Pasien lama akan mendapatkan berkas rekam medis sebelumnya dan pasien baru akan mendapatkan berkas rekam medis yang baru. Setelah 
pasien kembali dari poli atau IGD berkas rekam medis akan masuk ke unit rekam medis. Pengolahan berkas rekam medis di unit rekam medis rawat jalan dimulai dari assembling, coding, indexing, danfiling (12).

Hasil wawancara dengan petugas rekam medis, alur berkas rekam medis pasien rawat jalan di RS Paru Batu sudah sesuai dengan alur yang ditetapkan oleh Depkes RI. Menurut Budi alur berkas rekam medis yang efektif dan penataan ruang rekam medis yang disesuaikan dengan alur akan mempercepat pelayanan yang diberikan kepada pasien. Selain itu dengan adanya alur maka pelayanan dapat dilakukan dengan efektif dan efisien (9).

Alur berkas rekam medis dimulai dari TPP. Pada pasien lama berkas rekam medis akan dicari di bagian penyimpanan sementara untuk pasien baru akan dibuatkan berkas rekam medis yang baru. Setelah jam pelayanan rawat jalan selesai, berkas rekam medis harus kembali ke unit rekam medis paling lambat 1 jam sebelum jam kerja berakhir. Sementara pada rawat inap berkas rekam medis harus kembali ke unit rekam medis paling lambat 24 jam setelah pasien keluar. Berkas rekam medis yang sudah kembali ke unit rekam medis akan segera dilakukan assembling, coding, indexing hingga kemudian berkas rekam medis kembali ke rak penyimpanan $(9,12)$.

Hasil wawancara di RS Paru Batu, pengolahan berkas rekam medis pasien rawat inap dimulai dari tempat pendaftaran pasien. Pada bagian ini petugas menyiapkan berkas rekam medis pasien rawat inap. Kemudian berkas masuk ke bangsal perawatan dan kembali ke bagian rekam medis. Berkas rekam medis yang seharusnya kembali paling lambat 24 jam setelah pelayanan selesai akan tetapi di RS Paru Batu berkas rekam medis baru kembali beberapa hari setelah pasien keluar. Menurut hasil wawancara dengan petugas rekam medis yang diakumulasi dari beberapa perawat, alasan keterlambatan pengembalian berkas rekam medis ratarata perawat mengatakan beban kerja kerja perawat terlalu tinggi, alasan ini juga didukung oleh komite keperawatan ketika diskusi. Alasan tersebut yang menyebabkan perawat belum melengkapi berkas rekam medis setelah pasien pulang dan baru mengembalikan ke unit rekam medis setelah beberapa berkas rekam medis telah terisi lengkap. Alasan tersebut didukung oleh penelitian dari Fardaningrum et al yang menyatakan bahwa alasan perawat atas keterlambatan pengembalian berkas rekam medis dikarenakan beban kerja yang tinggi dan belum selesainya pengisian berkas rekam medis ketika pasien pulang. Menurut Budi et al salah satu parameter yang digunakan untuk mengetahui mutu rekam medis di rumah sakit khususnya yang melibatkan kegiatan assembling adalah ketepatan waktu pengembalian berkas ke bagian rekam medis. Dari pernyataan tersebut dapat disimpulkan bahwa keterlambatan pengembalian berkas rekam medis di RS Paru Batu dapat mengurangi mutu dari rekam medis tersebut (9).

Berkas rekam medis yang telah kembali ke bagian rekam medis, akan diolah oleh petugas rekam medis. Pengolahan berkas rekam medis di bagian rekam medis dimulai dari bagian assembling. Pada bagian assembling berkasrekam medis diurutkan berdasarkan urutan form dan dilakukan evaluasi kelengkapannya. Rekam medis yang kurang lengkap akan dikembalikan ke ruang perawatan untuk dilengkapi (9). Berdasarkan hasil wawancara hal yang sama juga dilakukan di RS Paru dalam kegiatan assembling. Berkas rekam medis akan diurutkan dan dievaluasi kelengkapan berkas rekam medisnya. Hasil observasi dari laporan kelengkapan berkas rekam medis dan hasil wawancara dengan petugas rekam medis, kelengkapan berkas rekam medis pada tahun 2014 sekitar $16 \%$ dari standar 100\%. Kesimpulan hasil diskusi menyatakan bahwa ketidaklengkapan berkas rekam medis diakibatkan tenaga kesehatan kurang displin dalam pengisian rekam medis. Selain itu, kesadaran dan motivasi tenaga kesehatan akan penting kelengkapan pengisian rekam medis juga kurang. Hal ini didukung oleh hasil penelitian Sari et al bahwa motivasi ekstrinsik seperti prosedur kerja dan kondisi pekerjaan berpengaruh signifikan terhadap kelengkapan pengisian berkas rekam medis oleh dokter (19). Hal ini didukung oleh hasil penelitian Pribadi et al yang menyatakan bahwa ada hubungan yang signifikan antara motivasi perawat dengan pengisian asuhan keperawatan (20). Menurut Budi et al, mutu rekam medis yang melibatkan kegiatan assembling selain ketepatan waktu adalah kelengkapan formulir rekam medis dan kelengkapan pengisian pada berkas rekam medis (9).

Di RS Paru Batu alur berkas rekam medis rawat inap setelah diurutkan dan dievaluasi kelengkapannya kemudian dilakukan pengkodean. Pengkodean penyakit dan tindakan dengan menggunakan ICD 10 dan ICD 9 CM. Pengkodean yang dilakukan sudah sesuai dengan pedoman penyelenggaran rekam medis yang ditentukan oleh Depkes RI. Setelah dilakukan pengkodean juga dilakukan pengindeksan. Pengindeksan di RS Paru Batu dilakukan secara komputerisasi. Setelah pengindeksan selesai maka dilakukan sistem penyimpanan. Sistem penyimpanan dilakukan dengan menggunakan sistem penyimpanan desentralisasi dimana antara penyimpanan berkas rekam medis pasien rawat jalan dan pasien rawat inap dipisahkan. Kendala yang ada di bagian penyimpanan adalah kurangnya rak penyimpanan yang mengakibatkan banyak berkas yang masih tercecer. Keadaan tersebut dapat menyulitkan petugas rekam medis ketika mencari dan mempersiapkan berkas rekam medis yang dibutuhkan. Sementara menurut Rodriguez-Cerillo et al penyiapan dokumentasi rekam medis merupakan salah satu cerminan pelayanan yang ada didalam rumah sakit (21).

Hasil penelitian mengidentifikasi perbedaan alur pasien rawat jalan dengan standar sedangkan alur pasien rawat inap dan rawat jalan sudah sesuai. Meskipun alur pasien telah sesuai pada rawat inap namun alur rekam medik belum sesuai dan didapatkan alur yang panjang pada rawat inap pasien dari IGD. Tidak ditemukan ketidaksesuaian alur berkas rekam medik pada pelayanan rawat jalan.

Saran yang dapat diberikan dari hasil penelitian adalah penambahan tenaga khusus untuk mendistribusikan berkas rekam medis, hal ini penting mengingat bahwa isi rekam medis adalah rahasia. Untuk mempercepat layanan dan memperpendek alur di IGD perlu adanya tenaga administrasi di IGD dan pemotongan alur pelayanan IGD. Untuk menjamin fungsi rekam medik sebagai informasi berkelanjutan perlu dipastikan bahwa jika pasien lama maka akan diberikan berkas rekam medis yang lama. Selain itu rumah sakit juga perlu mengembangkan SOP yang mengatur pengembalian berkas rekam medis dan pengisian rekam medis, adanya panita rekam medis serta adanya evaluasi secara berkala baik yang dilakukan secara internal dibagian rekam medis maupun evaluasi yang dihadiri oleh setiap kepala ruangan dan poli. 


\section{DAFTAR PUSTAKA}

1. Tsai P-F, Chen P-C, Chiu C-Y, and Chen K-Y. Information System Evaluation for Hospital Admission Management: A Case Study. IIE Annual Conference Proceedings. Reno USA, 21-25 May 2011; p. 1-7.

2. Vest JR, Gamm LD, Ohsfeldt RL, Zhao H, and Jasperson JS. Factor Associated with Health Information Exchange System Usage in a Safety-Net Ambulatory Care Clinic Setting. Journal of Medical System. 2012; 36(4): 2455-2461.

3. Fichman RG, Kohli R, and Krishnan R. Editorial Overview-the Role of Information Systems in Healthcare: Current Research and Future Trends. Journal Information Systems Research. 2011; 22(3): 419-428.

4. Lee M, Delaney C, and Moorhead S. Building a Personal Health Record from a Nursing Perspective. International Journal of Medical Informatics. 2007; 76(2):S308-S316.

5. Matsuo T, Gochi A, Hirakawa T, Ito T, and Kohno Y. Outpatient Flow Management and Ophthamic Electronic Medical Records System in Hospital Using Yahgee Document View. Journal of Medical System. 2010; 34(5): 883-889.

6. Wibe $T$, Edwin E, Husby EH, and Vedal $T$. Implementation of Nursing Care Plan in the Electronic Patient Record (EPR) Findings and Experiences. Studies in Health Technology and Informatics. 2006; 122: 309-313.

7. David GC, Chand D, and Sankaranarayanan B. Error Rates in Physician Dictation: Quality Assurance and Medical Record Production. International Journal of Health Care Quality Assurance. 2014; 27(2): 99-110.

8. Rosenthal MM, Cornett PL, Sutcliffe KM, and Lewton E. Beyond the Medical Record: Other Modes of Error Acknowledgment. Journal of General Internal Medicine. 2005; 20(5): 404-409.

9. Budi SC. Manajemen Unit Kerja Rekam Medis. Bantul: Quantum Sinergis Media; 2011.

10. Susanto G dan Sukadi. Sistem Informasi Rekam Medis pada Rumah Sakit Umum Daerah (RSUD) Pacitan Berbasis Web Base. Indonesian Jurnal on Computer Science Speed. 2012; 9(3): 40-46.

11. Kusumarini P. Penerimaan Dokter dan Waktu Tunggu pada Peresepan Elektronik Dibandingkan Peresepan Manual. Jurnal Manajemen Pelayanan Kesehatan. 2011; 14(3): 133-138.

12. Departemen Kesehatan Republik Indonesia.
Pedoman Penyelenggaraan dan Prosedur Rekam Medis Rumah Sakit di Indonesia. Jakarta: Depkes RI; 2006.

13. Guwandi J. Rahasia Medis. Jakarta: Fakultas Kedokteran Universitas Indonesia; 2005.

14. Nursa'adah R. Pengaruh Simplifikasi Prosedur Pelayanan Pelanggan terhadap Tingkat Kepuasan Pelanggan Pelayanan Perpanjangan Surat Ijin Mengemudi (SIM) di SIM Corner Kota Surabaya. Jurnal Kebijakan dan Manajemen Publik. 2013; 1(1): 20-26.

15. Mukti WY, Hamzah A, dan Nyorong M. Pengaruh Mutu Layanan Kesehatan terhadap Kepuasan Pasien Rawat Inap di Rumah Sakit Woodward Kota Palu. Jurnal Adminsitrasi \& Kebijakan Kesehatan Indonesia. 2013; 2(3):35-41.

16. Suharyanta D dan A'yunin Q. Analisis Tingkat Kualitas Pelayanan Jasa Menggunakan Metode Sercive Quality (Servqual) Fuzzy di Instalasi Radiologi RSUD Panembahan Senopati Batul Tahun 2012. Jurnal Kesehatan Masyarakat (Journal of Public Health). 2013; 7(1): 43-53.

17. Kumar BD, Kumari CM, Sharada MS, and Mangala MS. Evaluation of the Medical Records System in an Upcoming Teaching Hospital--A Project for Improvisation. Journal of Medical Systems. 2012;36(4): 2171-2175.

18. Fardaningrum A. Aspek Pengendalian Tingkat Keterlambatan Pengembalian Dokumen Rekam Medis dari Rawat Inap ke Assembling di Rumah Sakit Bhayangkara Semarang Periode Februari Tahun 2013. [Skripsi]. Universitas Dian Nuswantoro, Semarang. 2013.

19. Sari DP. Analisis Karakteristik Individu dan Motivasi Ekstrinsik terhadap Kinerja Dokter dalam Kelengkapan Pengisian Rekam Medis pada Pasien Rawat Jalan Di RS Hermina Depok. [Tesis]. Universitas Indonesia, Jakarta. 2011.

20. Pribadi A. Analisis Pengaruh Faktor Pengetahuan, Motivasi, dan Persepsi Perawat Tentang Supervisi Kepala Ruang terhadap Pelaksanaan Dokumentasi Asuhan Keperawatan di RSUD Kelet Provinsi Jawa Tengah di Jepara. [Tesis]. Universitas Diponegoro, Semarang. 2009.

21. Rodríguez-Cerrillo $M$, Fernández-Díaz $E$, InurrietaRomero A, Poza-Montoro A. Implementation of a Quality Management System According to 9001 Standard in a Hospital in the Home Unit: Changes and Achievements. International Journal of Health Care Quality Assurance. 2012; 25(6): 498-508 